\title{
Penerapan Sistem Penunjang Keputusan Menggunakan Algoritma Naive Bayes Pada konsep Human Resource Information System (HRIS) (Studi kasus :Penerusan Kontrak Kerja Karyawan di PT. XYZ)
}

\author{
Dwi Remawati ${ }^{1)}$, Ruvyanto Dwi Nugroho ${ }^{2)}$, Paulus Harsadi ${ }^{3)}$ \\ ${ }^{1,3)}$ Program Studi Teknik Informatika STMIK Sinar Nusantara Surakarta \\ ${ }^{2)}$ Program Studi Sistem Informasi STMIK Sinar Nusantara Surakarta \\ ${ }^{1)}$ dwirema@sinus.ac.id; ruvyanto1996@gmail.com²); ${ }^{3}$ paulusharsadi@sinus.ac.id
}

\begin{abstract}
One of the valuable assets in a company is human resources (HR). Human Resource Information System (HRIS) has emerged as one of the drivers of competitiveadvantage and strategic decision making tool. One of the HRIS task is employee recruitment. Employees become an important role. Therefore, this research is conducted forclassification of employee status determination using the Naïve Bayes methods. One of the duties of employees is to provide service to customer in the process of purchasing goods until the payment transaction process directly. Because of the large number of contract employees at the time of certain events, it requires companies to select every three months for the continuation of the work contract period for employees according to store needs so that the company's employee payroll expenses do not exceed the budget. One of the criteria is for being able to work in flexible groups between the ages of 17 and 25 for contract employees with a minimum of high school or vocational education. The purposes of this study are to design and build a Decision Support System application for the Continuation of Employee Employment Contracts Using the Nä̈ve Bayes Method at PT. XYZ Retail. The result of the research is the application using the naïve bayes method with an accuracy rate of $90 \%$.
\end{abstract}

Keywords: Nä̈ve Bayes, Contract Employees, Decision Support Systems, Human Resource Information System

\section{PENDAHULUAN}

Beberapa tahun terakhir bahkan sebelum era revolusi industry 4.0, perusahaan mulai menyadari bahwa teknologi informasi bisa memberikan dampak positif kepada perusahaan. Meningkatnya peran teknologi informasi dalam berbagai bidang membuat perusahaan mulai mencari keunggulan dan pemanfaatan teknologi informasi jika digabungkan dengan sumber daya manusia atau human resource $(H R)$ dalam perusahaan.

Manajemen sumber daya manusia atau human resource management (HRM) merupakan asset yang sangat bernilai bagi perusahaan dalam kontribusinya yang berkaitan dengan persaingan perusahaan diera sekarang (Schroeder, 2012).Human Resource Information System (HRIS) yang merupakan pemanfaatan teknologi informasi dalam HRM dapat mengumpulkan, mengecek, menyimpan, memanipulasi, menganalisa dan memberikan laporan yang lebih informatif untuk pengambilan keputusan oleh stake holder perusahaan (Nagendra \& Deshpande, 2014).

Tanjim Tomanna menunjukkan peran yang besar HRIS dalam transformasi sumber daya manusia di perusahaan(Tomanna, Gerbi, Hossin, \& Zhang, 2018). Bahkan tidak hanya diperusahaan tetapi secara keseluruhan dapat memberikan efek positif bagi suatu Negara (Aksoy \& Sallam, 2018).

Penggunaan HRIS begitu signifikan diperusahaan. bahkan HRIS perlu diintegrasikan dengan fungsi bisnis yang lain sehingga lebih cerdas dalam kapasitasnya untuk meningkatkan efisiensi dari Human resource Planning(Nagendra \& Deshpande, 2014).

Human Resource Departement (HRD) merupakan bagian yang menangani sumber daya manusia dalam perusahaan dan salah satunya adalah perekrutan pegawai. Semakin besar 
sebuah perusahaan, maka semakin banyak pula jumlah karyawan yang bekerja diperusahaan tersebut.Perusahaan dapat menyerahkan sebagian pelaksanaan pekerjaan kepada perusahaan lainnya melalui perjanjian pemborongan pekerjaan atau penyediaan jasa pekerja/buruh yang dibuat secara tertulis.Dalam perusahaan biasanya terdiri dari beberapa macam pegawai, seperti karyawan outsourcing, karyawan kontrak dan karyawan tetap. Perusahaan kadang melakukan pengangkatan karyawan kontrak atau tetap dalam jangka waktu satu tahun sekali. Bagian HRD melakukan penilaian terhadap hal tersebut. Penilaian dilakukan untuk menjaring karyawan yang berkompeten. Bagian SDM mengalami beberapa kendala dalam proses penilaian penetapan status dalam segi teknis ataupun efektifitas. HRIS dibutuhkan dalam hal ini untuk memberikan rekomendasi yang tepat yaitu dengan menerapkan Sistem Penunjang Keputusan (SPK). Beberapa penelitian SPK untuk perekrutan pegawai telah dilakukan antara lain menggunakan metode Fuzzy(Ablhamid, Santoso, \& Muslim, 2013), kombinasi Fuzzy logic dan AHP(Chen, 2009), TOPSIS(Siregar et al., 2017) dan masih banyak metode yang lain yang ternyata sangat membantu dalam proses perekrutan karyawan.

Naïve Bayes adalah metode klasifikasi yang dapat digunakan untuk mendukung keputusan yang termasuk dalam metode data mining dan termasuk dalam classifier statistic yang bisa digunakan untuk memprediksi probabilitas keanggotaan class sehingga juga dapat diterapkan dalam SPK.

\section{TINJAUAN PUSTAKA}

\subsection{Penelitian Terkait}

Berikut beberapa penelitian yang menggunakan metode Naïve Bayes untuk SPK :

Penggunaan metode Naïve Bayes untuk implementasi SPK penyakit hati menunjukkan bahwa penggunaan algoritma tersebut cukup efektif dan memberikan prediksi yang akurat dengan menggunakan model data mining dalam mengekstrak data dan memanfaatkannya dalam SPK. Hasil penelitian ini juga dapat digunakan sebagai alat untuk pelatihan perawat atau mahasiswa kesehatan untuk mendiagnosis pasien dengan penyakit hati (G Subbalakshmi M, 2011).

Naïve Bayes juga digunakan untuk Clinical Decision Support System (CDSS) yang memanfaatkan clound computing technique yang berisi big medical dataset untuk menentukan diagnosis pasien(Liu, Lu, Ma, Chen, \& Qin, 2016). Survey yang dilakukan menunjukkan metode Naïve Bayes termasuk salah satu metode yang sering digunakan dalam CDSS (Vaghela, Bhatt, \& Mistry, 2015).

\subsection{Human Resource Information System (HRIS)}

Human Resource Information System (HRIS) merupakan sistem yang mengkolaborasi dan menggabungkan antar aktivitas yang berhubungan dengan manajemen Human Resource Departement (HRD) dengan teknologi informasi dalam satu sistem melalui penggunaan Enterprise resource planning (ERP) guna mendukung pengambilan keputusan. HRIS merupakan kunci penting dalam HRD untuk mengotomatisasi beberapa fungsi dan meningkatkan efesiensi (Nagendra \& Deshpande, 2014).Kemampuan HRIS dapat meningkatkan efisiensi dalam administrasi di HRD yang akan memberikan efek ke perencanaan maupun pengambilan keputusan oleh HRD.

a. Penerapan HRIS dalam perusahaan memiliki beberapa kelebihan :

b. Semua data terpusat

c. Mengurangi kesalahan manusia

d. Keamanan data 
e. Mengurangi pekerjaan yang manual menggunakan kertas

f. Pengambilan keputusan lebih akurat dan terencana dengan baik

\subsection{Naïve Bayes}

Penggunaan Nä̈ve Bayes Classifiers tidak hanya di SPK. Beberapa penelitian di image (Dong-Chul Park, 2016), text klasifikasi(Dai, Xue, Yang, \& Yu, 2007),(Tang, Kay, \& He, 2016),(Granik \& Mesyura, 2017), bahkan dibidang manufaktur (Karandikar, McLeay, Turner, \& Schmitz, 2015).

Naïve Bayes merupakan metode klasifikasi yang dapat digunakan untuk mendukung keputusan yang termasuk dalam metode data mining dan termasuk dalam classifier statistic yang bisa digunakan untuk memprediksi probabilitas keanggotaan class.Kelebihan NBC (Naïve Bayes Classifier) adalah sederhana tetapi memiliki tingkat akurasi yang tinggi dengan asumsi independensi (ketidakketergantungan) yang kuat (naif). Yang dimaksud independensi yang kuat adalah sebuah data yang tidak berkaitan dengan ada atau tidaknya data yang sama(Nilsson, 1965),(Cestnik, 1990),(Kevin P. Murphy, 2006).

Langkah perhitungan dengan metode Naive Bayes (Dong-Chul Park, 2016) :

1. Membaca dataset training

2. Menghitung jumlah kelas/label

$$
P\left(C_{i}\right)=\frac{S_{i}}{S}
$$

Dimana $S_{i}$ adalah jumlah training sample pada class $C_{i}$, dan $S$ adalah jumlah training sample.

3. Menghitung nilai probabilitas hipotesis

$$
\mathrm{P}(\mathrm{Ci} \mid \mathrm{X})=P\left(C_{i} \mid X\right) \frac{P(X \mid C i) P(C i)}{P(X)} .
$$

Keterangan :

$\mathrm{P}\left(\mathrm{C}_{\mathrm{i}} \mid \mathrm{X}\right)=$ Probabilitas hipotesis $\mathrm{Ci}$ jika diberikan fakta atau record $\mathrm{X}$ (Posterior probability)

$\mathrm{P}\left(\mathrm{X} \mid \mathrm{C}_{\mathrm{i}}\right) \quad=$ Mencari nilai parameter yang memberi kemungkinan yang paling besar (likehood)

$\mathrm{P}\left(\mathrm{C}_{\mathrm{i}}\right) \quad=$ Prior probability dari $\mathrm{X}$ (Prior probability)

$\mathrm{P}(\mathrm{X}) \quad=$ Jumlah probability tuple yg muncul

4. Solusi kemudian dihasilkan

III. METODE PENELITIAN

3.1. Teknik Pengumpulan Data

a. Studi Pustaka

Dengan mempelajari materi atau teori tentang langkah penerusan kontrak kerja melalui beberapa literatur acuan dan jurnal ilmiah yang berkaitan dengan materi penelitian untuk membuat aplikasi sistem pendukung keputusan penerusan kontrak kerja karyawan dengan metode Naive Bayes di PT. XYZ. 


\section{b. Observasi}

Data karyawan kontrak PT XYZ yang sudah melewati masa training ataupun sudah mendekati kontrak 2 tahun lamanya.

c. Wawancara

Dalam penelitian ini, wawancara dilakukan dengan tujuan untuk mendefinisikan dan menganalisa kebutuhan perangkat lunak yang akan dikembangkan. Hasil yang diperoleh dari wawancara adalah mengenai cara menentukan karyawan yang layak meneruskan kontrak kerja, dan gambaran yang berkaitan dengan perusahaan.

\subsection{Perancangan dan Desain Sistem}

Sistem adalah sutu kesatuan yang terdiri dari bagian-bagian yang berkaitan satu sama lain yang berusaha mencapai suatu tujuan dalam suatu lingkungan kompleks.Pada tahap perancangan dan desain sistem pendukung keputusan, digunakan beberapa alat antara lain adalah sebagai berikut :

\section{a. Data Flow Diagram}

Data Flow Diagram terdiri dari pemecahan dari diagram konteks diantaranya admin akan melakukan login kemudian admin menginputkan data kriteria karyawan kontrak, data training, dan data testing untuk melakukan proses transaksi nä̈ve bayes kemudian terdapat hasil laporan data karyawan yang layak maupun tidak layak dari hasil transaksi naïve bayes.

b. Desain Input Output

Desain input dan output adalah rancangan interface dari sistem pendukung keputusan.

c. Desain Database

Dalam tahap perancangan database untuk sistem pendukung keputusan penerusan kontrak kerja karyawan dengan menggunakan metode naive bayes di PT. XYZ,digunakan ERD (Entity Relational Database).

\subsection{Implementasi}

Pada tahap implementasi aplikasi sistem pendukung keputusan menentukan karyawan yang layak meneruskan masa kontrak kerja menggunakan bahasa pemrograman PHP dan menggunakan DBMS ( Database Management System) MySQL.

\subsection{Pengujian}

Pengujian dilakukan menggunakan uji fungsional dan validitas. Pengujian fungsional menggunakan metode Black Box yaitu metode yang berdasarkan pada kebutuhan fungsional perangkat lunak yang dibuat. Uji Validitas digunakan untuk menghitung prosentase akurasi keberhasilan. Pengujianmenggunakan perbandingan antara dataset training dengan hasil keputusan metode naive bayes.

\section{HASIL DAN PEMBAHASAN}

Pada proses penghitungan menggunakan metode Nä̈ve Bayes, penulis menggunakanvariable-variabel berdasarkan data trainingyaitu data karyawan kontrak yang diperoleh dari PT. XYZ, dengan nilai kreteria antara lain penampilan, absensi, kejujuran, kedisiplinan, kecepatan kerja, ketelitian, hasil kerja dan komunikasi. 
Tabel 1. Data Training

\begin{tabular}{|l|l|l|l|l|l|l|l|l|}
\hline $\mathbf{V 1}$ & $\mathbf{V 2}$ & $\mathbf{V 3}$ & $\mathbf{V 4}$ & $\mathbf{V 5}$ & $\mathbf{V 6}$ & $\mathbf{V 7}$ & $\mathbf{V 8}$ & $\mathbf{K}$ \\
\hline 1 & 1 & 2 & 2 & 2 & 2 & 1 & 1 & $\mathrm{~L}$ \\
\hline 1 & 1 & 1 & 2 & 1 & 1 & 2 & 2 & $\mathrm{~L}$ \\
\hline 2 & 2 & 1 & 1 & 2 & 2 & 2 & 2 & $\mathrm{~L}$ \\
\hline 2 & 1 & 1 & 2 & 1 & 1 & 1 & 1 & $\mathrm{~L}$ \\
\hline 1 & 1 & 1 & 2 & 1 & 2 & 1 & 2 & $\mathrm{~L}$ \\
\hline 2 & 1 & 1 & 2 & 2 & 2 & 1 & 1 & $\mathrm{~L}$ \\
\hline 1 & 1 & 1 & 2 & 2 & 1 & 1 & 1 & $\mathrm{~L}$ \\
\hline 2 & 2 & 2 & 2 & 3 & 2 & 2 & 2 & $\mathrm{TL}$ \\
\hline 1 & 2 & 2 & 2 & 2 & 2 & 2 & 2 & $\mathrm{TL}$ \\
\hline 1 & 1 & 1 & 1 & 2 & 1 & 2 & 1 & $\mathrm{~L}$ \\
\hline 1 & 1 & 1 & 1 & 2 & 2 & 1 & 2 & $\mathrm{~L}$ \\
\hline 1 & 1 & 1 & 2 & 2 & 2 & 1 & 1 & $\mathrm{~L}$ \\
\hline 2 & 1 & 1 & 1 & 1 & 2 & 1 & 2 & $\mathrm{~L}$ \\
\hline 1 & 1 & 1 & 1 & 2 & 1 & 1 & 2 & $\mathrm{~L}$ \\
\hline 2 & 2 & 2 & 2 & 3 & 2 & 3 & 1 & $\mathrm{TL}$ \\
\hline 1 & 1 & 1 & 1 & 2 & 2 & 1 & 2 & $\mathrm{~L}$ \\
\hline 1 & 1 & 1 & 1 & 2 & 1 & 1 & 2 & $\mathrm{~L}$ \\
\hline 2 & 1 & 2 & 2 & 2 & 2 & 2 & 1 & $\mathrm{TL}$ \\
\hline 1 & 1 & 1 & 1 & 2 & 2 & 1 & 1 & $\mathrm{~L}$ \\
\hline 1 & 1 & 1 & 1 & 1 & 1 & 1 & 2 & $\mathrm{~L}$ \\
\hline
\end{tabular}

\section{Keterangan}

Skala nilai $1-100$ dengan kategori nilai sebagai berikut.
a. V1 (Penampilan) : $1=(\leq 80), 2=(75-79), 3=(<75)$
b. V2 (Absensi) : $1=(\leq 80), 2=(75-79), 3=(<75)$
c. V3 (Kejujuran) : $1=(\leq 80), 2=(75-79), 3=(<75)$
d. V4 (Kedisiplinan) : $1=(\leq 80), 2=(75-79), 3=(<75)$
e. $\quad$ V5 (Kecepatan Kerja) : $1=(<80), 2=(75-79), 3=(<75)$
f. V6 (Ketelitian) : $1=(\leq 80), 2=(75-79), 3=(<75)$
g. V7 (Hasil Kerja) : $1=(\leq 80), 2=(75-79), 3=(<75)$
h. V8 (Komunikasi) : $1=(\leq 80), 2=(75-79), 3=(<75)$

Berikut contoh kasus yang mengacu pada data training di Tabel 1.Pada PT. XYZ terdapat seorang karyawan kontrak, yang sudah selesai melewati masa training, karyawan tersebut memiliki nilai penampilan 80 , nilai absensi 80 , nilai kejujuran 79 , nilai kedisiplinan 78 , nilai kecepatan bekerja 78, nilai ketelitian 78 , nilai hasil kerja 78, dan nilai komunikasi 77. Berdasarkan data training diatas, akan ditentukan layak atau tidak untuk perpanjangan kontrak sebagai karyawan.Maka proses perhitungan dengan teorema bayes berdasarkan studi kasus diatas hasilnya sebagai berikut :

1. Menghitung jumlah class / label (diambil dari rumus no.(1))

a. $\mathrm{P}(\mathrm{Y}=$ Layak $)=16 / 20$ "Jumlah data layak dibagi dengan keseluruhan data"

b. $P(Y=$ Tidak Layak $)=4 / 20$ "Jumlah data tidak layak dibagi dengan keseluruhan data".

2. Menghitung jumlah kasus dengan class yang sama.

a. $\quad \mathrm{P}($ Penampilan $\mid$ Layak $)=12 / 16$

$\mathrm{P}($ Penampilan $\mid$ TidakLayak $)=1 / 4$

b. $\quad \mathrm{P}$ (Absensi $\mid$ Layak $)=15 / 16$

$\mathrm{P}($ Absensi $\mid$ Tidak Layak $)=1 / 4$

c. $\quad \mathrm{P}($ Kejujuran $\mid$ Layak $)=1 / 16$

$\mathrm{P}($ Kejujuran|Tidak Layak $)=4 / 4$

d. $\quad \mathrm{P}($ Kedisiplinan $\mid$ Layak $)=7 / 16$

$\mathrm{P}($ Kedisiplinan $\mid$ Tidak Layak $)=4 / 4$ 

e. $\quad \mathrm{P}($ Kecepatan Kerja $\mid$ Layak $)=11 / 16$
$\mathrm{P}($ KecepatanKerja $\mid$ TidakLayak $)=3 / 4$
f. $\quad P($ Ketelitian $\mid$ Layak $)=9 / 16$
$\mathrm{P}($ Ketelitian $\mid$ Tidak Layak $)=4 / 4$
g. $\quad \mathrm{P}($ Hasil Kerja $\mid$ Layak $)=3 / 16$
$\mathrm{P}($ Hasil Kerja $\mid$ TidakLayak $)=4 / 4$
h. $\quad \mathrm{P}($ Komunikasi $\mid$ Layak $)=10 / 16$
$\mathrm{P}($ Komunikasi $\mid$ TidakLayak $)=2 / 4$

3. Kalikan semua variabel Layak dan Tidak Layak

a. Likehood of Layak

$$
\begin{aligned}
& =\frac{16}{20} \times \frac{12}{16} \times \frac{15}{16} \times \frac{1}{16} \times \frac{7}{16} \times \frac{11}{16} \times \frac{9}{16} \times \frac{3}{16} \times \frac{10}{16} \\
& =0,00069704
\end{aligned}
$$

b. Likehood of Tidak Layak

$$
\begin{aligned}
& =\frac{4}{20} \times \frac{1}{4} \times \frac{1}{4} \times \frac{4}{4} \times \frac{4}{4} \times \frac{3}{4} \times \frac{4}{4} \times \frac{4}{4} \times \frac{2}{4} \\
& =0,0046875
\end{aligned}
$$

4. Hitung Class Layak dan Tidak Layak(diambil dari rumus no.(2))

a. Probability of Layak

$$
\begin{aligned}
& =\frac{0,00069704}{(0,00069704+0,0046875)} \times 100 \% \\
& =0,129452098 \times 100 \% \\
& =13 \%
\end{aligned}
$$

b. Probability of Tidak Layak

$$
\begin{aligned}
& =\frac{0,0046875}{(0,00069704+0,0046875)} \times 100 \% \\
& =0,8705479019 \times 100 \% \\
& =87 \%
\end{aligned}
$$

5. Bandingkan hasil nilai kelas Layak dan Tidak Layak.

6. Hasil yang diperoleh, menunjukkan bahwa nilai probabilitas tertinggi ada pada kelas (P|Layak) sehingga dapat disimpulkan bahwa Karyawan Kontrak tersebut Tidak Layak mendapatkan perpanjangan masa kontrak kerja.

\subsection{Perancangan Sistem}

Tahap perancangan sistem ini menjelaskan model dari program yang dibangun, sehingga nanti dapat tercipta suatu sistem yang baik. Pada tahap ini akan diuraikan dan dijelaskan mengenai diagram konteks, HIPO (Hierarki Input Proses Output), DFD (Data Flow Diagram), ERD (Entity Relasionship Data).

\subsubsection{Diagram Konteks}

Aliran data yang dijabarkan secara global untuk menggambarkan penggunaan data dari sumber data terdiri dari 3 entitas yaitu admin, karyawan, dan pimpinan. Admin berperan dalam proses olah data kriteria, data training, dan data testing. Pimpinan akan mendapatkan informasi keputusan data karyawan yang layak dan tidak layak mendapat penerusan kontrak kerja karyawan serta laporannya. Karyawan mendapatkan informasi yang layak dan tidak layak untuk meneruskan masa kontrak kerjaseperti pada Gambar 1 


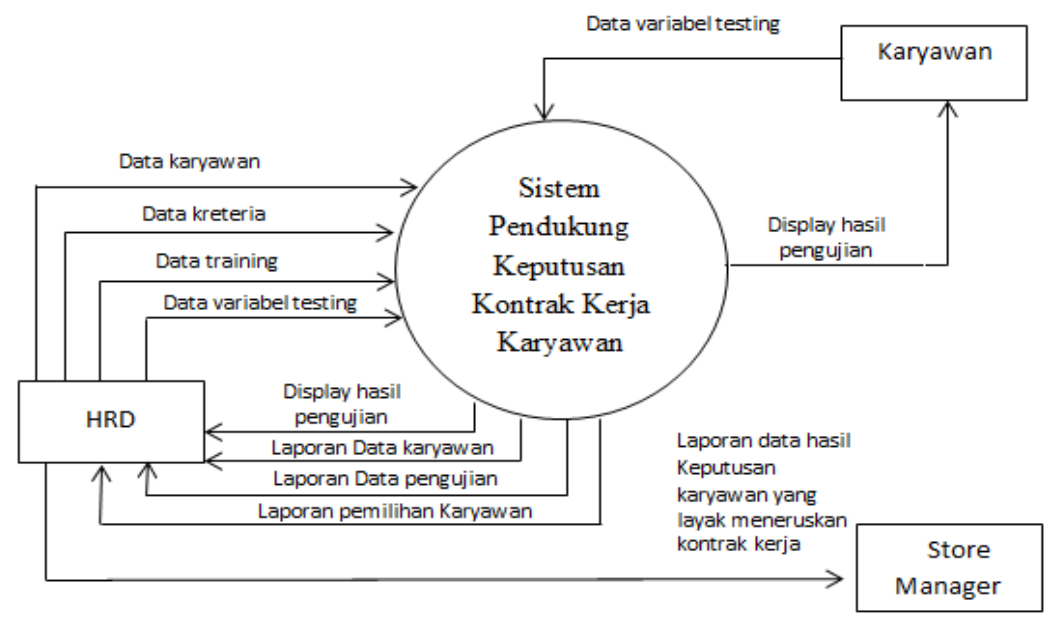

Gambar 1. Diagram Konteks

\subsubsection{HIPO (Hierarki Input Proses Output)}

Sistem paling awal dari Sistem Pendukung Keputusan Penerusan Kontrak Kerja Karyawan menggunakan Metode Naïve Bayes sebelum adanya turunan data. Pada bagian ini terdiri dari Maintanance Data Master diantaranyaproses Input yaitu inputdata karyawan, inputdata kreteria, dan inputdata trainning, berikutnya ada proses pengolahan dimana perhitungan dilakukan untuk menentukan kelayakan karyawan dan yang terakhir laporan. Diagram HIPO yang dirancang terlihat pada Gambar 2.

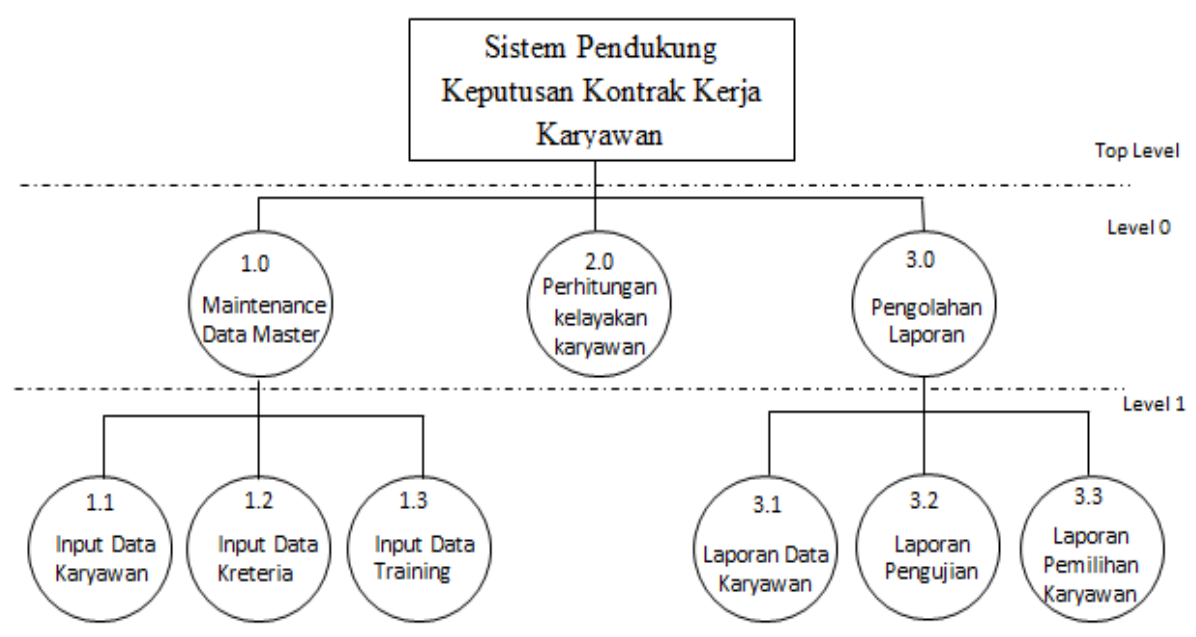

Gambar 2. HIPO

\subsubsection{Data Flow Diagram (DFD)}

Data Flow Diagram level 0 yang penulis rancang untuk sistem pendukung keputusan penerusan kontrak karyawan yang layak mendapat penerusan masa kontrak kerja seperti pada Gambar 3. 


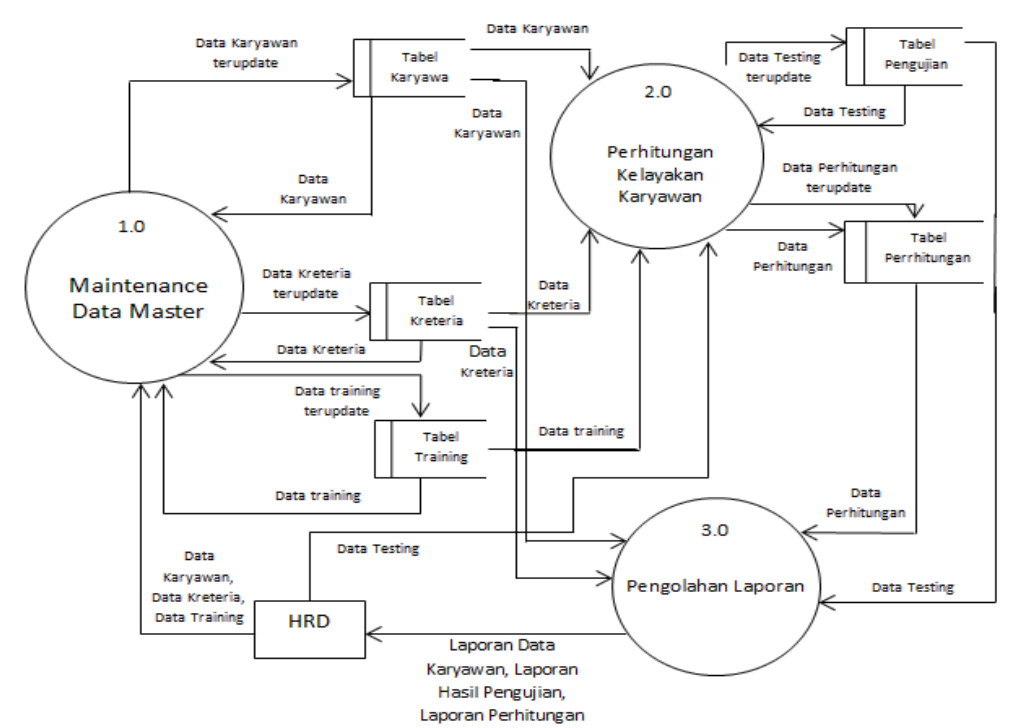

Gambar 3. DFD Level 0

\subsubsection{ERD (Entity Relationship Data)}

ERD (Entity Relationship Diagram) adalah teknik yang digunakan untuk memodelkan kebutuhan data dari suatu organisasi, sering digunakan oleh System Analys pada tahap analisis untuk membantu menggamrkan proses analisis. Proses memmbuat ERD dengan membuat teknik diagram atau alat peraga yang menggambarkan desain database relasional dari sistem yang dikembangkan. ERD sistem pendukung keputusan yang penulis rancang tampak pada Gambar 4

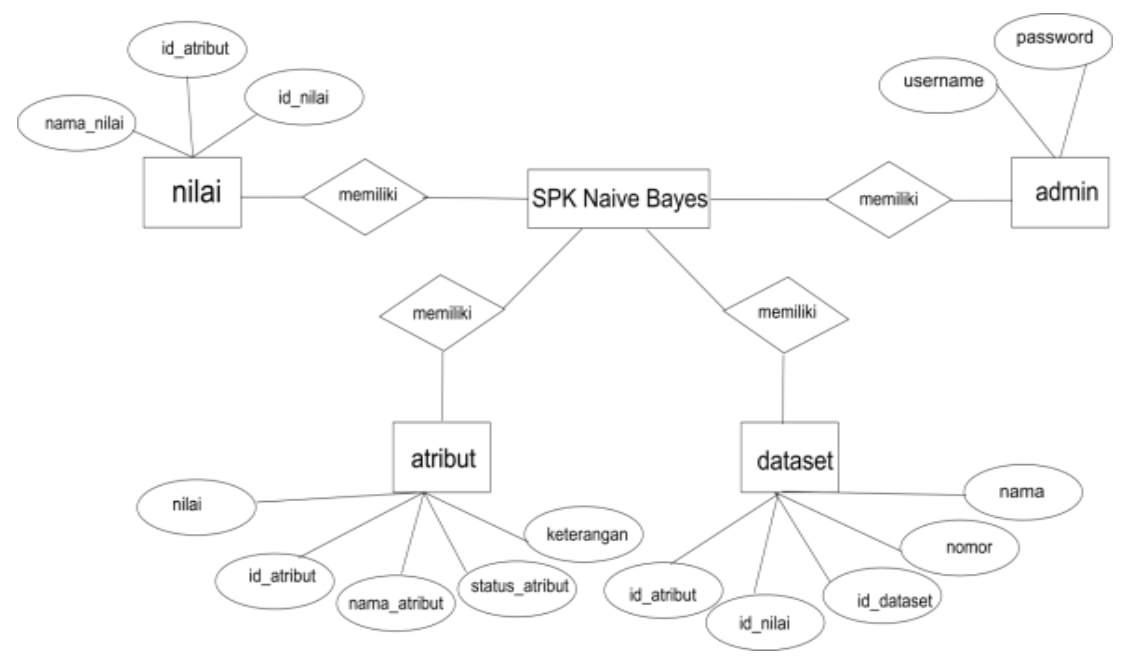

Gambar 4. ERD

\subsection{Implementasi}

Pada tahap implementasi sistem ini adalah tahap akhir dari pengembangan sistem SDLC, tahap ini adalah tahap dimana semua tahap dan rancangan serta aplikasi yang telah dibuat dan aplikasi yang sudah dilakukan pengujian kemudian diimplementasikan untuk menentukan karyawan kontrak yang layak meneruskan masa kontrak kerjanya, berikut adalah hasil implementasi sistem. 


\subsubsection{Tampilan Menu Perhitungan}

Halaman menu perhitungan menampilkan proses perhitungan dengan metode naïve bayes berdasarkan kriteria yang sudah diketahui. Menu tersebut ditampilkan pada Gambar 5 .

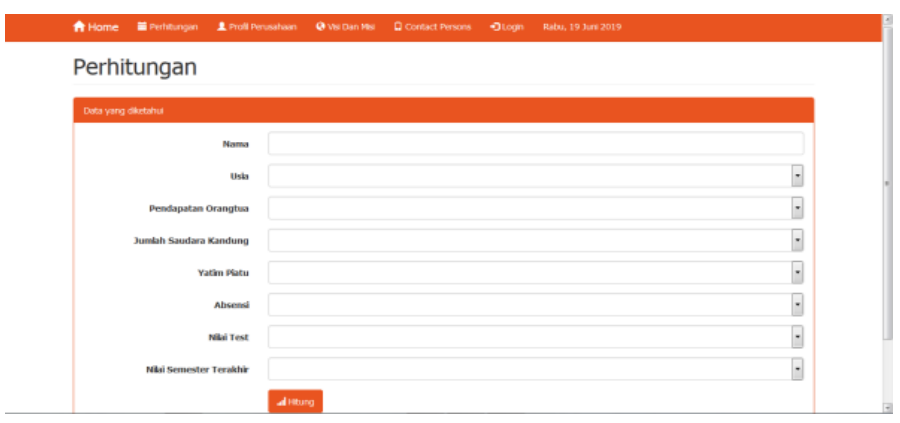

Gambar 5. Menu Perhitungan

\subsubsection{Tampilan Laporan Data}

Menampilkan laporan data perorangan beserta rincian proses hitung dengan metode naïve bayes ditampilkan pada Gambar 6.

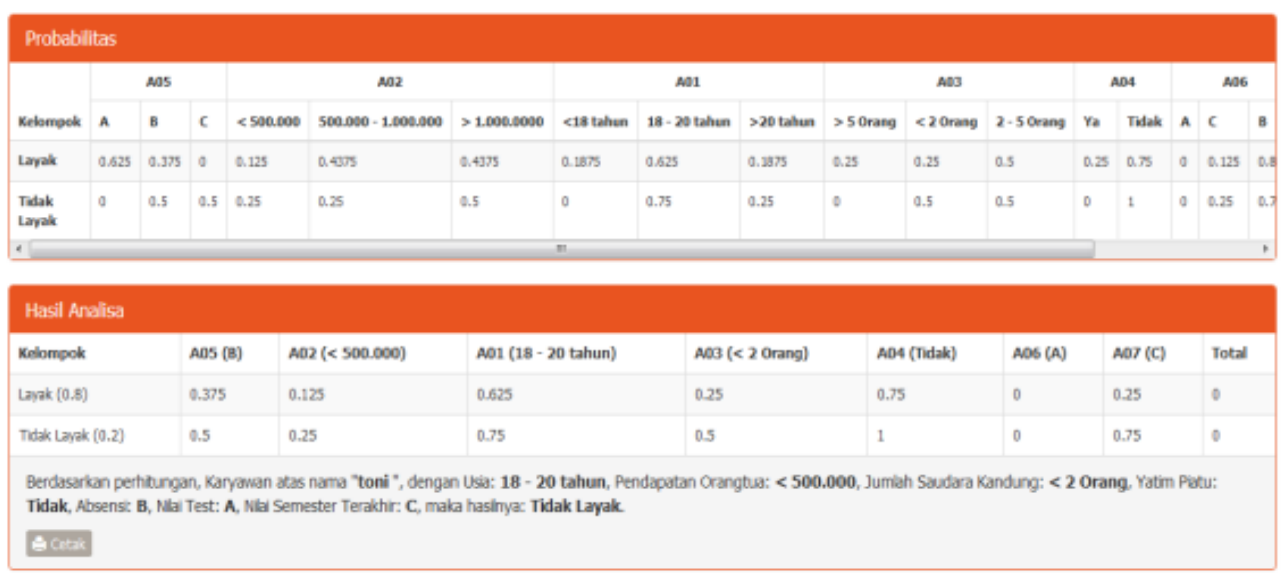

Gambar 6. Laporan Data

\subsubsection{Tampilan Cetak Laporan Perhitungan}

Tampilan laporan digunakan admin ataupun HRD untuk mencetak hasil dari perhitungan menggunakan metode naive bayes yang menghasilkan suatu keputusan yang nantinya dapat diserahkan kepada store manager toko. Gambar 7 menunjukkan gambar Tampilan Cetak Laporan Perhitungan .

LAPORAN HASIL KEPUTUSAN KARYAWAN KONTRAK LUWES GENTAN

J. Songgolangit Pondok Baru RT 03/12 Gentan, Baki Suoharjo, Jawa Tengah 57155 Telp.(0271) 637273

http://www.luwes.co.id Email:luwesgentanøgmail.com

Dicetak pada hari : Sabtu, 29 Juni 2019

Hasil Analisa Probabilitas

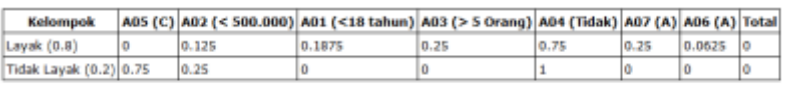

HASII KEPUTUSAN

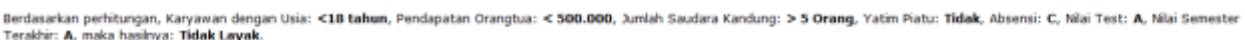

Gambar 7. Cetak Laporan 


\subsection{Pengujian}

a. Pengujian Black Box

Pada tabel 2. merupakan hasil pengujian black box. Pengetesan program dilakukan menggunakan pengujian fungsional untuk menguji aplikasi yang dibuat sudah sesuai dengan perancangan atau belum.

Tabel 2. Kesimpulan Hasil Pengujian Fungsionalitas

\begin{tabular}{|l|l|l|c|}
\hline No & Kasus Pengujian & Item Pengujian & Hasil \\
\hline 1. & Verivikasi Login & Menu Login & Valid \\
\hline 2. & Simpan Data & Form Kriteria & Valid \\
\hline & & Form Nilai Kriteria & Valid \\
\hline 3. & & Form Data Training & Valid \\
\hline & & Form Kriteria & Valid \\
\hline & & Form Nilai Kriteria & Valid \\
\hline 4. & Edit Data & Form Data Training & Valid \\
\hline & & Form Kriteria & Valid \\
\hline & & Form Nilai Kriteria & Valid \\
\hline 5. & Hapus Data & Form Data Training & Valid \\
\hline & & Form Kriteria & Valid \\
\hline & & Form Nilai Kriteria & Valid \\
\hline 6. & Perhitungan & Form Data Training & Valid \\
\hline
\end{tabular}

\section{b. Pengujian Validitas}

Uji Validitas merupakan pengujian untuk mencari perbandingan antara hasil dari program yang dibuat apakah sama dengan hasil perhitungan manual. Tabel 3. Berisi hasil dari pengujian. Uji ini dilakukan pada setiap tahap proses perhitungan yang akhirnya akan terlihat bahwa program yang dibuat sesuai dengan algoritma yang digunakan.

Tabel 3. Hasil Pengujian Validitas

\begin{tabular}{|l|l|l|l|}
\hline No & Data Testing & Hasil SPK & Hasil Uji Validitas \\
\hline 1. & Layak & Layak & T \\
\hline 2. & Layak & Layak & T \\
\hline 3. & Layak & Layak & T \\
\hline 4. & Layak & Layak & T \\
\hline 5. & Layak & Layak & T \\
\hline 6. & Layak & Layak & T \\
\hline 7. & Layak & Layak & T \\
\hline 8. & Tidak Layak & Tidak Layak & T \\
\hline 9. & Tidak Layak & Layak & F \\
\hline 10. & Layak & Layak & T \\
\hline 11. & Layak & Layak & T \\
\hline 12. & Layak & Layak & T \\
\hline 13. & Layak & Layak & T \\
\hline 14. & Layak & Layak & T \\
\hline 15. & Tidak Layak & Tidak Layak & T \\
\hline 16. & Layak & Layak & T \\
\hline 17. & Layak & Layak & T \\
\hline 18. & Tidak Layak & Layak & F \\
\hline 19. & Layak & Layak & T \\
\hline 20. & Layak & Layak & T \\
\hline \multicolumn{2}{|l|}{ Jumlah hasil yang benar } & 18 \\
\hline
\end{tabular}


Keterangan :

$\mathrm{T}=$ True, Nilai benar apabila hasil data testing dengan perhitungan naïve bayes menunjukkan hasil yang sama.

$\mathrm{F}=$ False, Nilai salah apabila hasil data testing dengan perhitungan naïve bayes menunjukkan hasil yang berbeda.

Untuk menghitung akurasi dengan persamaan berikut :

$$
\begin{aligned}
\text { Akurasi } & =\frac{\text { Jumlah Klasifikasi Benar }}{\text { Jumlah Data Testing }} \times 100 \% \\
& =\frac{18}{20} \times 100 \% \\
& =90 \%
\end{aligned}
$$

Hasil Uji Validitas menunjukkan kinerja sistem sudah baik. Dengan penambahan data testing akan memungkinkan naiknya kinerja sistem.

\section{KESIMPULAN DAN SARAN}

\subsection{Kesimpulan}

Adapun kesimpulan yang didapat sebagai berikut:

1. Dengan Metode Nä̈ve Bayes bisa digunakan untuk membuat aplikasi pendukung keputusan penerusan kontrak kerja karyawan tersebut layak atau tidak dalam mendapatkan kesempatan perpanjangan kontrak di PT. XYZ. sistem pendukung keputusan ini masuk dalam kategori HRIS yang mendukung HRD dalam menjalankan perencanaan yang dilaksanakan.

2. Pengujian sistem pendukung keputusan penerusan kontrak kerja karyawan ini menggunakan metode Blackbox Test, dimana perangkat lunak yang dibangun secara fungsional pada aplikasi dapat berjalan dengan baik.

3. Tingkat akurasi yang dihasilkan pada sistim pendukung keputusan penerusan kontrak kerja karyawan menggunakan metode Naive Bayes adalah 90\%, dimana dengan penambahan data testing akan dapat memungkinkan naiknya kinerja sistem.

\subsection{Saran}

Dari penelitian yang telah dilakukan, maka kedepan dapat dikembangkan dengan proses bisnis lain di HRD untuk pengimplementasian HRIS secara menyeluruh di perusahaan.

Kedepan HRIS dapat di integrasikan dengan ERP perusahaan sehingga lebih efektif lagi dalam pemanfaatannya di HRD.

\section{DAFTAR PUSTAKA}

Ablhamid, R. K., Santoso, B., \& Muslim, M. A. (2013). Decision Making and Evaluation System for Employee Recruitment Using Fuzzy Analytic Hierarchy Process. International Refereed Journal of Engineering and Science, 2(7), 24-31.

Aksoy, A., \& Sallam, S. (2018). Factors Affecting Human Resources Information Systems in Developing Countries. Electronic Business Journal, 17(10), 33-40.

Cestnik, B. (1990). Estimating probabilities: a crucial task in machine learning. In ECAI, 90, 147-149. 
Chen, P. (2009). A Fuzzy Multiple Criteria Decision Making Model in Employee Recruitment. International Journal of Computer Science and Network Security, 9(7), 113-117. Retrieved from http://paper.ijcsns.org/07_book/200907/20090716.pdf

Dai, W., Xue, G. R., Yang, Q., \& Yu, Y. (2007). Transferring Naive Bayes classifiers for text classification. Proceedings of the National Conference on Artificial Intelligence, 1 , 540-545.

Dong-Chul Park. (2016). Image Classification Using Naïve Bayes Classifier. International Journal of Computer Science and Electronics Engineering (IJCSEE), 4(3), 135-139. Retrieved from http://www.vision.caltech.edu/html-files/archive.html

G Subbalakshmi M. (2011). Decision Support in Heart Disease Prediction System using Naive Bayes. Indian Journal of Computer Science and Engineering (IJCSE), 2(2), 170176.

Granik, M., \& Mesyura, V. (2017). Fake news detection using naive Bayes classifier. 2017 IEEE 1st Ukraine Conference on Electrical and Computer Engineering, UKRCON 2017 - Proceedings, 900-903. https://doi.org/10.1109/UKRCON.2017.8100379

Karandikar, J., McLeay, T., Turner, S., \& Schmitz, T. (2015). Tool wear monitoring using naïve Bayes classifiers. International Journal of Advanced Manufacturing Technology, 77(9-12), 1613-1626. https://doi.org/10.1007/s00170-014-6560-6

Kevin P. Murphy. (2006). naive bayes classifiers. University of British Columbia, 18, 371381.

Liu, X., Lu, R., Ma, J., Chen, L., \& Qin, B. (2016). Privacy-Preserving Patient-Centric Clinical Decision Support System on Naïve Bayesian Classification. IEEE Journal of Biomedical and Health Informatics, 20(2), 655-668. https://doi.org/10.1109/JBHI.2015.2407157

Nagendra, A., \& Deshpande, M. (2014). Human Resource Information Systems (HRIS) in HR Planning and Development in Mid to Large Sized Organizations. Procedia - Social and Behavioral Sciences, 133, 61-67. https://doi.org/10.1016/j.sbspro.2014.04.169

Nilsson, N. J. (1965). Learning machines.

Schroeder, H. (2012). The Importance of Human Resource Management in Strategic Sustainability: An Art and Science Perspective. Journal of Environmental Sustainability, 2(1), 1-9. https://doi.org/10.14448/jes.02.0004

Siregar, D., Rahim, R., Engineering, C., Islam, U., Singingi, K., Gatot, J., \& Km, S. (2017). Decision Support System Best Employee Assessments with Technique for Order of Preference by Similarity to Ideal Solution. International Journal of Recent Trends in Engineering and Research, 3(3), 6-17. https://doi.org/10.23883/ijrter.2017.3037.fj7lk

Tang, B., Kay, S., \& He, H. (2016). Toward Optimal Feature Selection in Naive Bayes for Text Categorization. IEEE Transactions on Knowledge and Data Engineering, 28(9), 2508-2521. https://doi.org/10.1109/TKDE.2016.2563436

Tomanna, T., Gerbi, D. Y., Hossin, M. A., \& Zhang, S. (2018). Impact of Information System on Transformation of Human Resource Performance: An Exploratory Study in Oromia Radio and Television Organization. Journal of Human Resource and Sustainability Studies, 06(01), 37-52. https://doi.org/10.4236/jhrss.2018.61025

Vaghela, C., Bhatt, N., \& Mistry, D. (2015). A Survey on Various Classification Techniques for Clinical Decision Support System. International Journal of Computer Applications, 116(23), 14-17. https://doi.org/10.5120/20498-2369 